Portland State University

PDXScholar

\title{
A Library and the Disciplines: A Collaborative Project Assessing the Impact of eBooks and Mobile Devices on Student Learning
}

\author{
Barbara C. Glackin \\ Portland State University, bglackin@pdx.edu \\ Roy W. Rodenhiser \\ Boise State University \\ Brooke Herzog \\ Boise State University
}

Follow this and additional works at: https://pdxscholar.library.pdx.edu/ulib_fac

Part of the Library and Information Science Commons Let us know how access to this document benefits you.

\section{Citation Details}

Glackin, Barbara C.; Rodenhiser, Roy W.; and Herzog, Brooke, "A Library and the Disciplines: A Collaborative Project Assessing the Impact of eBooks and Mobile Devices on Student Learning" (2014). Library Faculty Publications and Presentations. 158.

https://pdxscholar.library.pdx.edu/ulib_fac/158

This Post-Print is brought to you for free and open access. It has been accepted for inclusion in Library Faculty Publications and Presentations by an authorized administrator of PDXScholar. Please contact us if we can make this document more accessible: pdxscholar@pdx.edu. 


\begin{abstract}
A Library and the Disciplines: A Collaborative Project Assessing the Impact of eBooks and Mobile Devices on Student Learning Barbara C. Glackin, Roy W. Rodenhiser and Brooke Herzog Boise State University
\end{abstract}

\begin{abstract}
Author Note:
Barbara C. Glackin, Albertsons Library, Boise State University; Roy W.

Rodenhiser, School of Social Work, Boise State University; Brooke Herzog, School of Social Work, Boise State University.
\end{abstract}

The authors would like to gratefully acknowledge Wendi McFarland, LMSW and Victoria Thompson, LMSW for the organization and assistance brought to the research process.

Barbara C. Glackin is now at Millar Library, Portland State University. Correspondence concerning this article should be addressed to Barbara C. Glackin, Millar Library, Portland State University, 1875 SW Park Avenue, Portland, OR 97209.

Email: barbaraglackin@pdx.edu 


\begin{abstract}
With the proliferation of technology usage, it is essential to understand the effect of implementation of technology in the academic setting. Specifically, this article examines the impact of eBooks and mobile devices on student learning. A pilot study was conducted with three areas of interest. The first question of interest found that owning or having access to two or more mobile devices significantly increased respondents’ frequency of accessing eBooks. The second question examined the pros and cons of using mobile devices. Accessibility and cost savings were found as pros; while functionality and pedagogy were reported as drawbacks to mobile device usage. Furthermore, usability responses varied. The third question examined the effect of mobile device use on student learning. Findings show that eBooks and mobile device use in the classroom have a significant impact on the student's educational experience.
\end{abstract}

\title{
Keywords
}

eBooks; mobile devices; student learning; library; social work; nursing

\section{Introduction}

Since fall 2010, Boise State University, a university of 22,000 students, has actively engaged in exploring innovative strategies using eContent (resources available electronically) and mobile devices in student learning (Shadle, Perkins, Lincoln, Humphrey, \& Landrum, 2013). Albertsons Library, the School of Social Work, and the Provost's Office collaborated on a pilot project investigating the use of eBooks and mobile devices among social work students. In year two, the School of Nursing and nursing students joined the study. This collaborative pilot project 
was designed to investigate the impact of eBooks and mobile devices on student learning both quantitatively and qualitatively. The pilot project sought to answer three research questions:

1. Will the use of mobile devices affect students' access to library resources, especially eResources?

2. What pros and cons are there in using mobile devices?

3. How might the use of mobile devices affect student learning?

The project focused on purposefully embedding library eBooks into the student learning experience. Students were provided with mobile devices for accessing eBooks and other curriculum support materials. An integral component of the pilot study included ready access to eBooks and other electronic information resources (eResources). In order to investigate the impact of eBooks and mobile devices on student learning, discipline-specific social work and nursing titles were acquired by the Library. Additional eResources ranging from handbooks, manuals, dictionaries, encyclopedias, to streaming media provided curriculum support for social work and nursing students. Library eBooks were made available through the online catalog and selected eBooks were also accessible through the Social Work and Nursing library research guides (LibGuides ${ }^{\mathrm{TM}}$ http://guides.boisestate.edu/socialwork ;

http://guides.boisestate.edu/nursing). The library research guides highlighted other eResources such as streaming media, online databases, and eJournals. Students and faculty in both programs were already actively using the discipline-specific library guides as a starting point for their library, information, and research needs.

A variety of mobile devices were considered for use in the pilot project—iPads, Kindles and other eReaders, and netbooks, and their features and functionality were evaluated. An internet browser, the ability to view documents, and the capability to support multiple eBook 
software platforms were mandatory on project mobile devices. Amazon Kindles were excluded from the project due to the Arizona State University lawsuit about visually impaired students' accessibility issues with that device (Barron, 2011). Accessibility features of possible mobile devices were also carefully considered. Project staff selected Apple iPad 1s and HP mini 2012 netbooks as the devices distributed to student participants at the beginning of each class for a semester-long loan. Although the 2012 Horizon Report (Johnson, Adams, \& Cummins, 2012) separates tablets from other mobile tools by limiting mobile to hand-held, call-making devices and makes a distinction between tablets and tablet computers, for purposes of this project, mobile devices refers to tablets and netbooks.

\section{Literature Review}

Wifi, the proliferation of electronic reference, information, and academic resources, new devices and technologies, and curriculums incorporating active student engagement have all coalesced around mobile learning. According to Morris and Maynard (2010), access to information anytime, anywhere is the defining characteristic of 'mobile.' This literature review summarizes the mobile and supporting technological evolutions first and then using the three research questions, investigates the integration of mobile learning, mobile devices, and eBooks among nursing and social work students.

Beginning in 2002, the Higher Education Horizon Report (hereafter Report) annually shares emerging trends and technologies predicted to impact colleges and universities in the coming years. The 2005 Report (New Media Consortium [NMC], 2005) features commentary on rising handheld device functionality, increasing access to the Internet, and proliferating ubiquitous wireless. In 2006, the Report (NMC, 2006) states: “[m]obile and personal technology 
is increasingly being viewed as a delivery platform for services of all kinds" (p. 3) and "phones in their pockets” (p. 5) as a technology to watch. The 2007 Report (NMC, 2007) notes “increasing demand by students for instant access and interactive experiences” (p. 3), and the "growing expectation to deliver services, content and media to mobile and personal devices" (p. 5). In 2008, the Report (NMC, 2008) recognizes that mobiles are an "affordable portable platform” (p. 2) for connecting and forecasts a growing demand for mobile content. The Amazon Kindle eBook reader is mentioned for the first time.

The 2009 Report (Johnson, Levine, \& Smith, 2009) for the third year labels mobiles, primarily mobile phones, as a trend to watch. The opportunity for higher education to reach out and connect using mobile content is listed as a critical challenge. Mobiles are placed on the timeto-adoption horizon of one year or less and reference and reading materials highlighted as accompanying educational applications. The 2010 Report (Johnson, Levine, Smith, \& Stone, 2010) comments on netbooks (or tablet computers) as a portable tool for learning and notes that eBooks are connecting with consumers for general reading but identifies availability, illustration limitations, and publishing of academic titles as obstacles. eBooks and mobiles make the 2011 Report's (Johnson, Smith, Willis, Levine, \& Haywood, 2011) technologies to watch list and the Apple iPad is mentioned as representing "a new class of tools that merges the utility of electronic book readers with web browsing” (p. 8). Also discussed is the transition from eBooks being simply a reproduction of print titles to evolving into a learning experience that optimized the features and functionalities of tablets. The educational opportunities interactive eBooks make possible is cited.

The 2012 Report (Johnson, Adams, \& Cummins, 2012) identifies active classroom learning and applications available on tablets as allowing students to connect the curriculum to 
real world experiences and issues. However, effectively using technology tools to engage with students is recognized as a challenge too. The 2013 Report (Johnson et al., 2013) expands on tablet computing as a technology to watch and focuses on device portability and "WiFi and cellular network connectivity” as promoting “learning inside and outside of the classroom” (p. 4) and features ways faculty are using tablets to enhance the curriculum.

Will the use of mobile devices affect social work and nursing students' access to library resources? Nursing and health care education were early adopters of using mobile technologies to connect students with information resources (Parsons, 2010). Boruff and Storie (2014) speak about mobile device adoption and use as a reference tool to locate medical care and drug information and find and read journal articles. With mobile technologies, students participating in clinical discussions are able use real time access to diagnostic and medical information to inform patient care (Kenny, Park, Van-Neste-Kenny, Burton, \& Qayyum, 2012). Lombardo and Honisett (2014) confirm the educational value of mobile devices as "useful for finding information quickly, especially when using medical reference, drug references, medical textbooks, and Pubmed” (p. 18). Although, Cooner’s (2004) article in Social Work Education took an early look at incorporating advances in technology into social work education, there are no recent articles about teaching or learning with mobile devices in the social work literature.

What pros and cons are there to using mobile devices? Mobile device use depends upon a number of factors. These include: the availability of a wireless Internet connection; reliability of the connection; purchase and maintenance costs of mobile devices; ease or difficulty of use; and comfort, or trouble, with eBook access and reading. West, Hafner, and Faust (2006) identify mobile device benefits of portability and ease of use with browser internet access. Parsons’ (2010) study found that internet and wireless connections and easy access to information were 
key reasons in students using mobile devices for education. Boruff and Storie (2014) cite discovery of, and access to, full-text journal articles and license authentication protocols as barriers to use.

As Morris and Maynard (2010) highlight and Lippincott (2010) emphasizes, in order to be truly mobile, devices need data plans. Kenny et al. (2012) include discussion about who should be responsible for paying for data plans while Lippincott (2010) asserts that the provision of data plans is outside of the scope of library services. Hahn and Bussell (2013) note that students may be unwilling to pay data plan costs.

In the Parson’s (2010) study, only 8\% of respondents identified mobile device purchase cost as a deciding factor for educational use. On the other hand, students encountering technical difficulties tend to stop using mobile devices (Taylor et al., 2010). According to Tees (2010) the main barrier to eBook acceptance is difficulty reading from the screen. A tablet's size, screen resolutions, and Internet access facilitate accessing information, viewing images, sharing content, and supporting student field- and lab-work (Johnson et al., 2012).

How might the use of mobile devices affect student learning? Ituma (2011) finds that mobile learning is active learning and the accompanying student engagement may foster an enriched learning environment. Mobile devices support learning by providing a reading experience where multimedia and collaborative elements can be incorporated (Miller, 2012). Student learning may be impacted by bringing faculty, students, and information resources together inside the clinical setting (Kenny et al., 2012). The 2012 Horizon Report (Johnson et al., 2012) cites numerous college and university studies where using tablets to engage with the curriculum “increased student engagement and enhanced learning” (p. 15). 
Other university research projects have also explored integrating mobile devices or eBooks into the curriculum. Gikas and Grant (2013) examined students’ perceptions of integrating mobile devices and social media interactions in three United States universities. Granado, Colmenares, Perez, and Catalodo (2013) researched using wifi and mobile devices to monitor and change laboratory hardware remotely and to complete laboratory practice when unable to access the physical facility. Martin and Ertzberger (2013) compared computers and mobile devices as learning tools in instructional design and technology courses. Viberg and Gronlund (2013) researched mobile technology in second and foreign language learning in China and Sweden. Ahmad and Brogan (2012) studied academic eBook use from the library perspective. Czechowski, Folb, and Wessel (2011) surveyed eBook usage by health sciences faculty and students.

\section{Methodology}

The pilot project assessment examines the three questions detailed in the Introduction. This study collected data over two academic school years and utilized two research tools: selfreport pre/post surveys and in-person focus groups. Student participation in the pilot project received human subject approval from the University’s Institutional Research Board.

Descriptive and statistical analyses were undertaken on the information collected from both the surveys and the focus groups. SPSS software (version 20) was used to perform both descriptive and bivariate statistical analyses to determine characteristics of participants, mobile device use, and how eResources impact student learning. The authors collaborated on creating the pre/post survey instruments.

\section{Sample}


The pilot study examined graduate social work and both undergraduate and graduate nursing students. The School of Social Work enrolls approximately 230 students state-wide with Bachelors programs in Boise and Twin Falls, and Master's programs in Boise, Coeur d'Alene, Lewiston, and Twin Falls. In the three distance programs classes are primarily face-to-face. The School of Nursing enrolls more than 630 students annually, with Bachelors and Master's programs.

Students enrolled in the targeted classes voluntarily chose to participate in the pilot study. Students were assured of the confidentiality of their responses and informed consent was obtained from all participants. Year one of the project targeted four sections of the same Social Work course taught at multiple campuses. Year two included multiple sections of two School of Nursing classes and one Social Work class. Participating classes were:

1. November 2010-May 2011 - Advanced Practice with Diverse Populations (SOCWRK 516) [2 sections, Boise and Twin Falls ; 2 control sections, Boise and Lewiston] ; approximately 25 students per section

2. August-December 2011 - Nursing in Health \& Illness (NURS 333) [2 sections] and Concepts of Population Health (NURS 522) [1 section] ; approximately 20 students per section

3. January-May 2012 - Nursing in Health \& Illness (NURS 333) [2 sections] ; approximately 20 students per section

4. May-August 2012 - Bereavement with Children (SOCWRK 597) [1 section ; Boise]* ; approximately 8 students

*No focus group conducted for this class. 
Pilot project participants agreed to a series of three activities; a pre-survey, a post-survey and a focus group. Survey completion required 10-20 minutes. Focus groups lasted approximately 60 minutes following a hosted participant lunch.

\section{Pre/Post Survey}

Developed by the research team, the pre/post surveys were designed to quantitatively and qualitatively investigate the three research questions. Data was gathered on the frequency of library eBook and mobile device use. Working in collaboration with faculty, the research team distributed the pre-survey electronically to students. Pre-surveys were used to determine student familiarity with, and prior use of, mobile devices and eBooks. Post-surveys were completed at the end of the semester and included all the questions from the pre-survey and additional questions focused on eBook usage and mobile device features.

The surveys were administered through an online survey system. They contained 36 questions addressing student demographics, use of eBooks and mobile devices, access patterns, and impact on coursework. Eleven of these questions asked participants' opinions about eBooks, mobile devices, and methods for accessing eBooks (research question 1). The survey also contained eight scored questions using a ten point Likert scale to quantify students' frequency of use and method for accessing eBooks. After year one, the survey was modified to include a question regarding the availability of wireless Internet access at home. The post-survey was used to gather data on how eBooks and mobile devices impacted the learning experience (research question 2). [See Appendix - Pre/Post Surveys.]

\section{Focus Groups}


A sixty minute focus group meeting was held at the end of the semester. The meetings were organized using a modified Delphi technique to uncover consensus driven qualitative data regarding students' perspective on the educational impact of mobile devices and eBooks. The Delphi technique, in contrast to other data gathering and analysis techniques, employs multiple iterations of structured questions designed to gain a common understanding of an issue. Typically, when employing a Delphi technique, the questions are given to the respondents several times using a group process to gather detailed information (Chambers, Wedel, \& Rodwell, 1992).

In this study, focus group participants responded to two iterations of structured inquiries. During the first iteration, the students wrote individual responses to the following statements:

1. Please discuss how using eBooks and mobile devices affected your educational experience. (Please list three or more ways they affected your educational experience.)

2. Please discuss what can be done differently to positively impact your experience with these technologies (mobile devices, eBooks). (Please list three or more ways we could have done things differently.)

3. Please discuss how you see mobile devices and eBooks impacting the future of education. (Please list three or more impacts).

Students' responses were displayed for review and discussion by the group. After the discussion, students responded to the same questions a second time with an opportunity to retain their initial responses or revise their answers. The final iteration of the focus group provided the research team with more detailed, yet consensus driven, information. Using inductive coding, a taxonomy of themes was developed from the responses. Multiple coders individually categorized the 
qualitative data. The categories were then compared among coders, to achieve coding consensus. Enumeration was used to quantify the data, and frequency distributions were run on the themes.

\section{Analysis and Findings}

\section{Surveys}

\section{Demographics}

The research team received a total of 164 surveys; 99 (60.4\%) pre-surveys at the beginning of the semester and 65 (39.6\%) post-surveys at the end of the semester. The mean age of participating students was 34 , and over $83 \%$ were female. The majority (77\%), were enrolled in classes at the metropolitan Boise State University campus, and the other 15\% and 8\% participated from the satellite campuses of Twin Falls and Lewiston, Idaho. Social work students returned 97surveys and nursing students returned 67. Seventy-two percent (72\%) of respondents reported owning or having access to two or more mobile devices with internet access. Due to the survey modification following year one, 85 students were asked if they had Internet access at home and of these, only three respondents (3.6\%) reported that they did not have Internet access at home.

\section{Pre/Post Survey Results}

\section{Research question 1: Will the use of mobile devices affect students' access to library resources, especially eResources?}

In both pre- and post-surveys, the students were asked how often they access eBooks, on a 10-point Likert scale. It was determined by using an independent t-test that owning or having access to two or more mobile devices significantly increased respondents' frequency of 
accessing eBooks by a mean difference of $2.28(\mathrm{t}(119)=2.28, \mathrm{p}<.001, \mathrm{SE}=0.53)$. Figure 1 displays reported frequency of accessing eBooks relative to number of mobile devices.

\section{(Insert Figure 1)}

Data from the pre-survey shows $68 \%$ of respondents (N=99) accessed eBooks, compared to $82 \%$ of respondents $(\mathrm{N}=65)$ stating they accessed eBooks in the post-survey. Using a chi-square test for significance, results confirm there was a significant increase of $14 \%$ more students accessing eBooks at the end of the study compared to the number of students accessing eBooks at the beginning of the study $\left(\mathrm{x}^{2}(1, \mathrm{~N}=164)=3.84, \mathrm{p}<.05\right)$.

Similarly, when examining additional differences in respondents’ reported frequency of eResource and mobile device use, it was determined that there were significant increases in respondents accessing the discipline-specific library research guides and frequency of using mobile devices and eBooks. An independent samples t-test for significance was utilized to determine these interactions (or respondents’ reported frequency of accessing eBooks was affected throughout the semester). Tables 1 and Figure 2 display these findings.

\section{(Insert Table 1)}

\section{(Insert Figure 2)}

Data from the pre-survey shows $20 \%$ of respondents $(\mathrm{N}=99)$ use the library catalog to access eBooks, compared to $43 \%$ of respondents $(\mathrm{N}=65)$ in the post-survey. Using a chi-square test for significance, results confirm there was a significant increase of 51\% (Figure 3, Presurvey with Figure 4, Post-Survey) more students accessing eBooks through the library at the end of the study compared to the beginning $\left(\mathrm{x}^{2}(1, \mathrm{~N}=164)=9.92, \mathrm{p}<.05\right)$. It is clear that students' usage of library eBooks increased because of involvement in this project. 


\section{(Insert Figure 3)}

(Insert Figure 4)

\section{Research question 2: What pros and cons are there in using mobile devices?}

Both surveys used open-ended questions to gather students’ perceptions on eBooks and mobile device use. Of the $62 \%(\mathrm{~N}=164)$ of respondents who listed three benefits of using eBooks, the most reported benefits included Accessibility (53\%), Usability (48\%), and Cost savings (20\%). Students reported eBooks are "easy to carry, easy to open, easy to access” and are “easily accessible (do not have to go to library or store to obtain).” Another student remarked that eBooks are beneficial in “price ... [and] ... convenience” and, regarding accessibility, one student reported "it’s easy to carry my books anywhere ... [since] ... all books are stored in one place” (Respondents \#161, \#157, \#89, \#91).

Within the $57 \%$ of respondents listing three drawbacks to using eBooks, the most reported themes were Usability with $40 \%$ of participants stating there were issues with usability, or Physical Characteristics, with respondents citing such things as their “eyes get tired” and eBooks are "hard to read" (Respondents \#161, \#159). The next most reported drawbacks were Functionality (25\% N=41) and Pedagogy (21\% N=35). Of these students, one stated with eBooks they “cannot highlight/underline the content” and that they “can’t keep [the] textbook to refer to it” for later use (Respondent \#73).

\section{Focus Group Results}

The focus groups gathered students’ perceptions of mobile devices, eBooks, and learning. Twenty-one nursing and thirty-six social work students participated in these discussions. Using inductive coding, taxonomy of themes was identified from the responses. Multiple coders 
categorized the qualitative data. Enumeration was used to quantify the data and frequency distributions were run on the themes. Eight themes identified within the responses include the following categories: Access, Usability, Functionality, Time, Cost, Wifi Access, Pedagogy, and Communication. These themes with example responses are shown in Figures 5 and 6.

\section{(Insert Figure 5)}

Students participating in the focus group discussions shared their thoughts on both positive and negative features of mobile devices. Comments about connectivity, functionality and time savings were all positive. Physical characteristics, especially those related to usability were of some concern, as was the lack of eBook reader applications that included sophisticated highlighting and note-taking functionality.

\section{Research question 3: How might the use of mobile devices affect student learning?}

\section{(Insert Figure 6)}

The open-ended questions included in the focus groups were revealing. Results predominately indicate a positive educational experience with mobile devices and eBooks. Social work and nursing students had overwhelmingly strong opinions regarding many positive aspects of eBook and mobile technology in education. In fact, in analyzing all the responses and the themes it was clear that 56 of the 57 focus group participants expressed positive views about their ability to access information using a mobile device.

When asked how eBooks and mobile devices affected students' education experience an overwhelming proportion of students, nearly $81 \%(\mathrm{~N}=46)$, stated using eBooks and mobile devices positively affected their educational experience by increasing their ability to access educational materials. Seventy-eight percent $(\mathrm{N}=44)$ of students reported they see eBooks and 
mobile devices impacting the future of education in a positive manner. Numbers of positive comments reported by students include the following: Usability (46 of 57); Pedagogy (33 of 57); Time (26 of 57); Financial cost (25 of 57); Communication (20 of 57); Features (19 of 57); and Wifi (14 of 57).

\section{Limitations}

The first project experienced some cross-contamination between the students in the participating classes and the control group classes. This resulted in the control group students resenting not being project participants and receiving mobile devices. Consequently control groups were not attempted after the first semester. Originally the pilot project research design was expected to focus on social work students over one semester. The first semester participation and response was so positive that the pilot was extended additional semesters and expanded to include nursing students.

Students appreciated receiving the mobile devices but complained that an accompanying data plan was not provided. Lack of a data plan was especially problematic for students with no in-home wireless service. The majority of students said that to make the mobile devices truly functional, a data plan was required and should be provided when sharing devices.

Much data was collected and at this time, analysis of the similarities and differences between the social work and nursing study groups has not been explored. The pilot project did not include access to, or analysis of, direct student performance measures. Data is based upon the indirect measure of students' perceptions of their educational experiences but not linked to defined academic requirements. There were questions not asked of the students that would have proved valuable. The authors were unable to establish how interactions with librarians associated 
with the project or preexisting familiarity with mobile devices influenced students' experiences and data gathered.

\section{Discussion/Interpretation}

This study explored students' use of mobile devices and reported frequency of library and eBook use. In Nursing, the mobile devices were used primarily in the clinical setting. Student nurses worked in hospitals and health care settings and provided direct patient care. The mobile devices provided point-of-need access to medical reference works, articles, handbooks, and eBooks about specific illnesses and injuries, treatment options, medications, and patient care. The ability to retrieve information while talking with patients and during clinical discussions between students and supervisors was perceived as facilitating knowledgeable conversations. Anecdotally, faculty emphasized how much this simplified both the teaching and learning

processes—discussions could just happen—-there was no starting a conversation, students going away and doing research, and then reinitiating the dialog at a later time. Mobile devices supporting the nursing clinical allowed students to directly connect what they were experiencing with needed information and what they were learning.

Working with diverse populations was the curricular focus for the first Social Work classes. During this course, students learn about different populations and explore their own social and cultural identities. Race, religion, ethics, society, gender, sexuality, and nationality are just some of the concepts investigated. The Library acquired numerous eBooks and licensed online media collections focused on different cultures, identities, and societies in support of the student investigations. Streaming media played an important role in these classes as students used videos and media clips to share impactful information, start conversations about differences 
and similarities, and begin to understand others' realities. Students enjoyed finding and sharing these visual pieces of information and faculty noted that using a short video could help students understand identities and differences more quickly and deeply.

Working with bereaved children was the second Social Work class involved in this project. Again students were provided with eBooks and other electronic resources to help them understand the unique parameters and protocols for developing relationships and working with children. Mobile devices were used by a couple of students to connect distantly to the class. This course involved supervised, direct fieldwork with bereaved children. At times, students used the mobile devices to connect with the children and through their joint exploration of the device's features, begin building a trusting relationship where conversation might happen.

The authors observed that the level of student engagement was consistently high throughout the project. Students were excited to hear about the eBook format and have access to information at point-of-need. They were happy to receive mobile devices for semester long use and immediately began experimenting and configuring them for personal use upon receipt (for example, setting up their email account access). Most importantly, students were able to easily find and access library resources. Using mobile devices instilled a sense of adventure in the classroom by providing a new discovery tool. eBook use by project participants increased significantly. Discussions with students indicated that they believed their learning was increased by study participation and exposure to the mobile devices and eBooks. Prior to, and throughout the project, students' technology adoption and comfort levels varied widely, yet overall students found using eBooks and mobile devices to be productive. Hence, this use positively impacted their educational experience.

\section{Practical Implications / Areas for future research}


The students' active participation in this project demonstrated their willingness to explore using eBooks and integrating mobile technology in the classroom. Easy access to information and applications supporting their classroom, clinical, and field work effectively enhanced student learning. This project was limited to a small sample size, no control group(s), and no direct measures of educational change. It is recommended that this pilot project be expanded in greater numbers across other disciplines and include in-depth indirect and direct assessment measures to provide analysis of educational change among study participants. These direct measures could be specific assignments, tests, or graded projects where mobile learning was an integral component of the activity. 


\section{Appendix - Pre/Post Surveys}

\section{[Pre-Survey (Distributed at the beginning of the semester)]}

1. Your age

2. Sex
a. Male
b. Female

3. Years of education

4. Do you have wireless Internet (WiFi) access at home?
a. Yes
b. No

5. I own or have access to the following devices. (Check all that apply.)
a. Desktop computer
b. Laptop computer
c. Mini computer (Netbook, other mini computer)
d. eReader (Kindle, iPad, other mobile reading device)
e. Mobile phone with Internet access
f. Other:

6. How often do you access eBooks? (10 point scale)
a. Very often
b. Often
c. Routinely
d. Occasionally
e. Seldom
f. Never

7. How do you access eBooks?
a. Desktop computer
b. Laptop computer
c. Mini computer (Netbook, other mini computer)
d. eReader (Kindle, iPad, other mobile reading device)
e. Mobile phone with Internet access
f. Other:

8. Where to you access eBooks?
a. Library catalog
b. Amazon.com, iBooks, Barnes\&Noble.com, etc.
c. Library social work guide
d. Google Books
e. Other:

9. Why do you use eBooks? (Check all that apply.)
a. Convenience 
b. Educational reading (not required for class)

c. Educational reading for class work

d. Fun

e. Portability

f. Other(s):

10. Please list 3 benefits of eBooks.

a.

b.

C.

11. Please list 3 drawbacks of eBooks.

a.

b.

c.

12. Which is your favorite way to access eBooks? (Choose 1)
a. Desktop computer
b. Laptop computer
c. Mini computer (Netbook, other small computer)
d. eReader (Kindle, iPad, other mobile reading device)
e. Mobile phone with Internet access
f. Other:

13. Please tell us why you chose your favorite device?

a.

14. Which is your least favorite way to access eBooks? (Choose 1)
a. Desktop computer
b. Laptop computer
c. Mini computer (Netbook, other small computer)
d. eReader (Kindle, iPad, other mobile reading device)
e. Mobile phone with Internet access
f. Other:

15. Please tell us why you chose your least favorite device?

a.

16. Do you access the Boise State University Nursing library guide? (10 point scale)
a. Very often
b. Often
c. Routinely
d. Occasionally
e. Seldom
f. Never 
[Post-Survey - Pre-survey questions plus these additional questions. (Distributed at the end of the semester.)]

17. Do you use eBooks in your coursework or research? (10 point scale)
a. Very often
b. Often
c. Routinely
d. Occasionally
e. Seldom
f. Never

18. How often to you use a portable electronic device (eDevice)? (10 point scale)
a. Very often
b. Often
c. Routinely
d. Occasionally
e. Seldom
f. Never

19. Do you use an eDevice to access eBooks? (10 point scale)
a. Very often
b. Often
c. Routinely
d. Occasionally
e. Seldom
f. Never

20. Do you use an eDevice in support of your coursework or research? (10 point scale)
a. Very often
b. Often
c. Routinely
d. Occasionally
e. Seldom
f. Never

21. Please list 3 benefits of eDevices:

a.

b.

c.

22. Please list 3 drawbacks of eDevices:

a.

b.

c.

23. Which eDevice do you use most often? (Choose 1)

a. iPad 

b. Kindle
c. Mini computer
d. Mobile phone with Internet access
e. Other:

24. Which eDevice do you use second most often? (Choose 1)
a. iPad
b. Kindle
c. Mini computer
d. Mobile phone with Internet access
e. Other:

25. Which eDevice do you use least often? (Choose 1)
a. iPad
b. Kindle
c. Mini computer
d. Mobile phone with Internet access
e. Other:

26. What is the one thing an eDevice does that you really like?

a.

27. What is the one thing you wish an eDevice could do that it doesn't?

a.

28. How important are the following eDevice features? (10 point rating scale - Very important to Not important)
a. Ease of use
b. Screen size
c. Ease of accessing eBooks
d. Ease of reading eBooks
e. Ease of searching eBooks
f. Weight
g. Screen resolution
h. Capability to adjust font size
i. Wireless connectivity
j. Input options (touch screen, key pad, key board)
k. Web browser
l. Storage capacity
m. Battery life
n. Durability
o. Capability to support other formats (PDF, HTML, Blackboard, others)
p. Add-ons (dictionary, annotation options, other)
q. Portability 
29. Which is the most important eDevice feature:

a.

30. Which is the least important eDevice feature:

a.

31. Why do you use an eDevice? (Check all that apply)
a. Convenience
b. Educational reading (not required for class)
c. Education reading (for class work)
d. Fun
e. Portability
f. Other(s):

32. Please discuss how online resources impacted your learning experience in this class.

a. 


\section{Mobile Devices and Frequency of}

Accessing eBooks

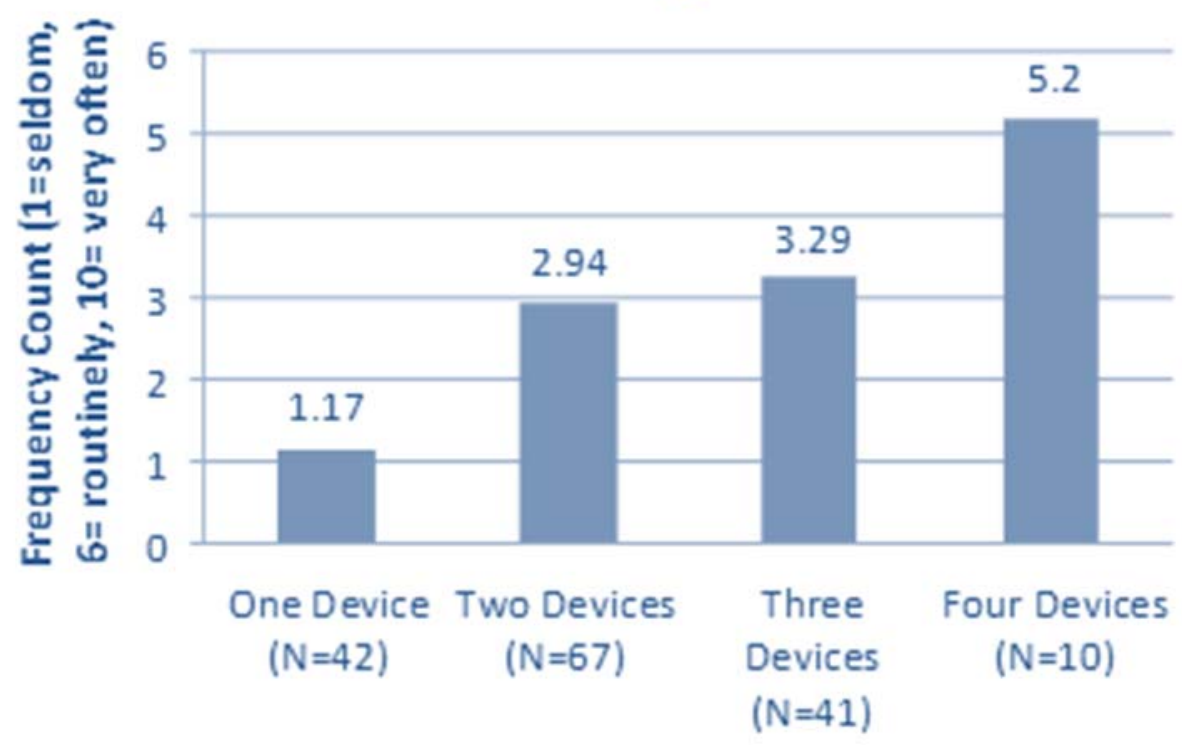

Mean difference of $2.28(t(119)=2.28, p<001,5 E=0.53)$

Figure 1. Mobile Devices and Frequency of Accessing eBooks 


\title{
Table 1
}

eResources and Mobile Device use Among Participants

On a Scale of 1-10 with 1 being "Never" and 10 being "Very Often"

Effects

Do you Access the Boise State University Social Work or Nursing Library Guide?

Pre Post

$4.09 \quad 5.23 \quad\left(\mathrm{t}\left(64=1.14,{ }^{*} \mathrm{p}<.05, \mathrm{SE}=.50\right)\right.$

Do you use a portable electronic device [mobile device] 2.43 to access eBooks?

$4.11 \quad\left(\mathrm{t}\left(64=1.68,{ }^{*} \mathrm{p}<.05, \mathrm{SE}=.67\right)\right.$

Do you use eBooks in your coursework or

$1.46 \quad 3.77$

$\left(\mathrm{t}\left(64=2.31,{ }^{*} \mathrm{p}=.000, \mathrm{SE}=.58\right)\right.$ research?

$\left(\mathrm{t}(64)=2.25,{ }^{*} \mathrm{p}=.011, \mathrm{SE}=.49\right)$

4

How often do you access eBooks?

\begin{abstract}
rand
\end{abstract}

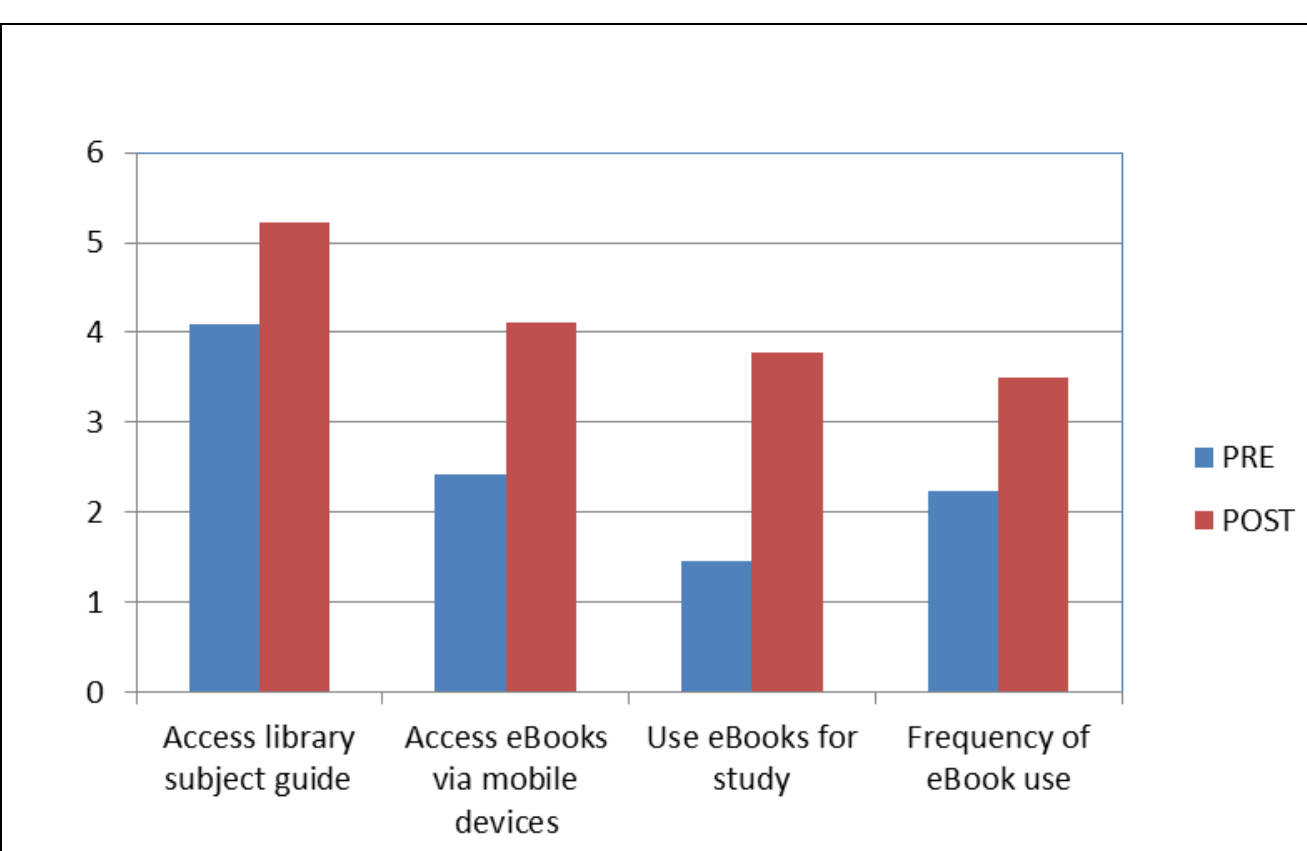

Figure 2. eResources and Mobile Device use Among Participants 


\section{Where do you access eBooks? (Pre)}

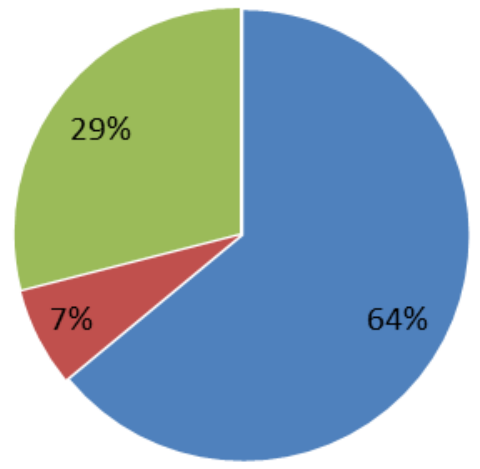

- Commercial Website - Library Guide - Library Catalog

Figure 3. eBook Access Points Pre-Survey

\section{Where do you access eBooks? (Post)}

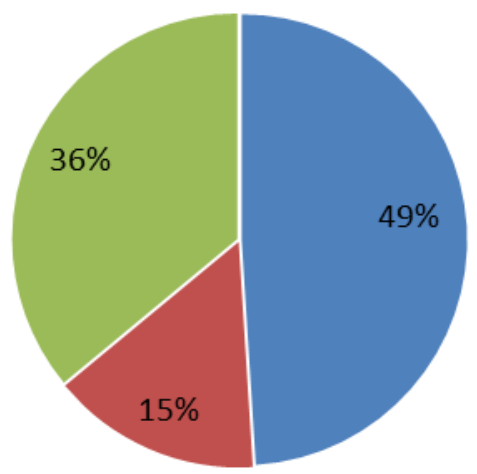

- Commercial Website

- Library Guide

- Library Catalog

Figure 4. eBook Access Points Post-Survey 


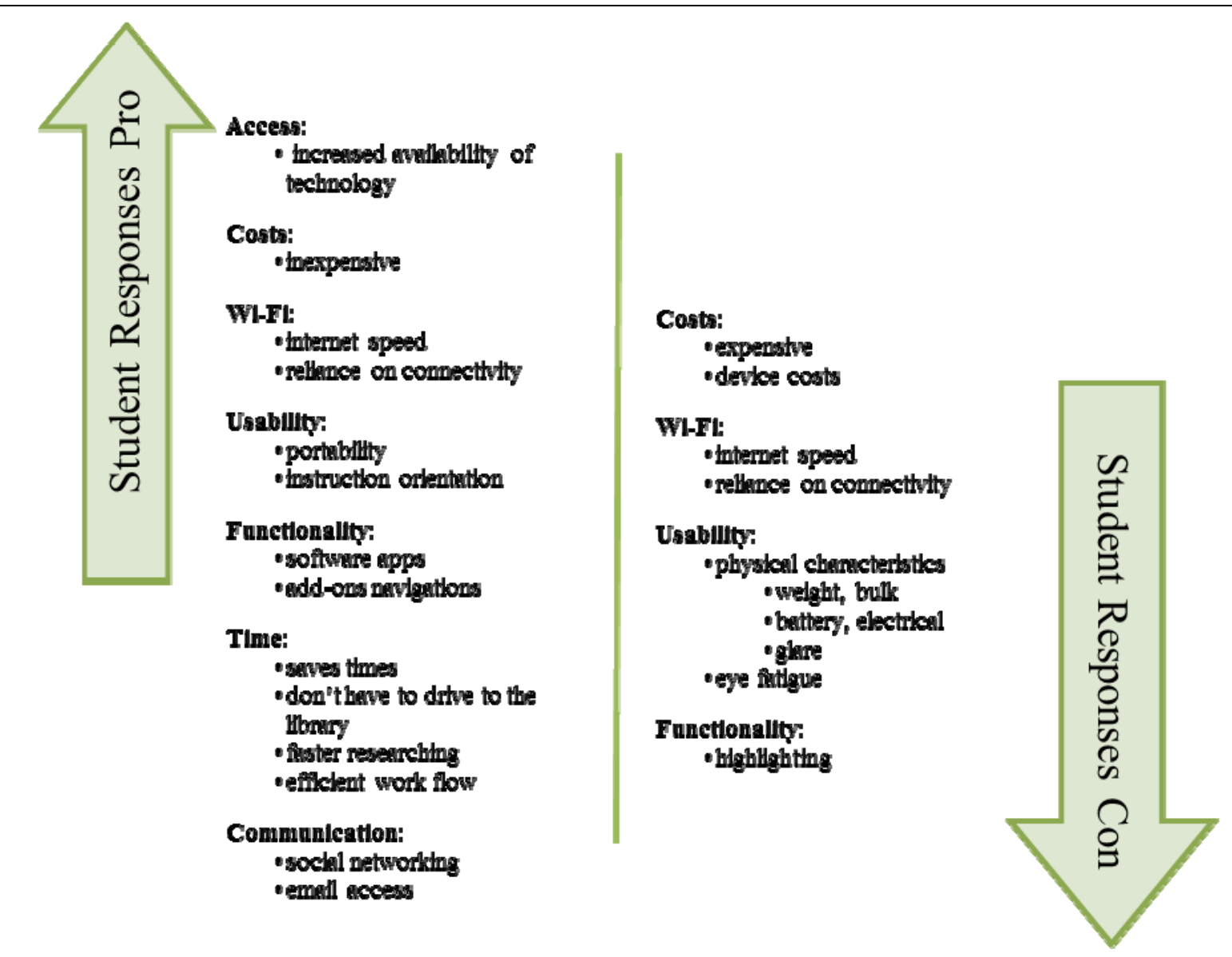

Figure 5. Pro and Con Focus Group Theme 


\begin{tabular}{|c|c|}
\hline \multicolumn{2}{|r|}{ Focus Group Themes on Student Learning Impact } \\
\hline Access & $\begin{array}{l}\text { Student responses related to access to educational information: } \\
\text { - Ability to download information anywhere } \\
\text { - Access to the library } 24 / 7 \\
\text { - Access to nursing and social work guides } \\
\text { - Access to pharmacological information }\end{array}$ \\
\hline Pedagogy & $\begin{array}{l}\text { Student responses related to learning: } \\
\text { - Access to texts makes learning fun and easy } \\
\text { - Impact on curriculum methods of delivery impact on student } \\
\text { learning styles }\end{array}$ \\
\hline Time & $\begin{array}{l}\text { Student responses related to temporal issues on education: } \\
\text { - Quick access to academic resources }\end{array}$ \\
\hline Communication & $\begin{array}{l}\text { Student responses to educational communication with individuals: } \\
\text { - Easier and faster to communicate with classmates and } \\
\text { instructors } \\
\text { - Information sharing }\end{array}$ \\
\hline
\end{tabular}

Figure 6. Focus Group Themes on Student Learning Impact 


\section{References}

Ahmad, P., \& Brogan, M. (2012). Scholarly use of e-books in a virtual academic environment: A case study. Australian Academic \& Research Libraries, 43(3), 189-213.

Barron, P. (2011). E-readers in the classroom. Transformations, 22(1), 133-138,143.

Boruff, J., \& Storie, D. (2014). Mobile devices in medicine: A survey of how medical students, residents, and faculty use smartphones and other mobile devices to find information. Journal of the Medical Library Association, 102(1), 22-30. doi:http://dx.doi.org/10.3163/1536-5050.102.0.006

Chambers, D., Wedel, K., \& Rodwell, M. (1992). Evaluating social programs. Boston, MA: Allyn and Bacon.

Cooner, T. (2004). Preparing for ICT enhanced practice learning opportunities in 2010 -- A speculative view. Social Work Education, 23(6), 731-744. doi:http://dx.doi.org/10.1080/0261547042000294509

Crowell, K., \& Shaw-Kokot, J. (2003). Extending the hand of knowledge: Promoting mobile technologies. Medical Reference Services Quarterly, 22(1), 1-9.

Cummings, J., Merrill, A., \& Borrelli, S. (2010). The use of handheld mobile devices: Their impact and implications for library services. Library Hi Tech, 28(1), 22-40.

Czechowski, L., Folb, B, \& Wessel, C. (2011). Clinical and academic use of electronic and print books: The Health Sciences Library System e-book study at the University of Pittsburgh. Journal of the Medical Library Association, 99(3), 218-228.

Gikas, J., \& Grant, M. (2013). Mobile computing devices in higher education: Student perspectives on learning with cellphones, smartphones, and social media. Internet and Higher Education, 19, 18-26. 
Granado, E., Colmenares, W., Perez, O., Catalodo, G. (2013). Remote experimentation using mobile technology. IEEE Latin American Transactions, 11(4), 1121-1126.

Hahn, J., \& Bussell, H. (2012). Curricular use of the iPad 2 by a first-year undergraduate learning community. Library Technology Reports, 48(8), 42-47.

Hsu, C-C., \& Sanford, B. (2007). The Delphi technique: Making sense of consensus. Practical Assessment, Research \& Evaluation, 12(10).

Available online: http://pareonline.net/getvn.asp?v=12\&n=10

Ismail, L. (2009). What they are telling us: Library use and needs of traditional and nontraditional students in a graduate social work program. Journal of Academic Librarianship, 35(6), 555-564.

Ituma, A. (2011). An evaluation of students’ perceptions and engagement with e-learning components in a campus based university. Active Learning in Higher Education, 12(1), 57-68.

doi:http://dx.doi.org/10.1177/1469787410387722

Johnson, L., Adams Becker, S., Cummins, M., Estrada, V., Freeman, A., \& Ludgate, H. (2013). The NMC Horizon Report (2013 higher education ed.). Austin, TX: New Media Consortium.

Johnson, L., Adams, S., \& Cummins, M. (2012). The NMC Horizon Report (2012 higher education ed.). Austin, TX: New Media Consortium.

Johnson, L., Levine, A., \& Smith, R. (2009). The 2009 Horizon Report. Austin, TX: New Media Consortium.

Johnson, L., Levine, A., Smith, R., \& Stone, S., (2010). The 2010 Horizon Report. Austin, TX: New Media Consortium. 
Johnson, L., Smith R., Willis, H., Levine, A., \& Haywood, K. (2011). The 2011 Horizon Report. Austin, TX: New Media Consortium.

Kenny, R., Park, C., Van-Neste-Kenny, J., Burton, P., \& Qayyum, A. (2012). Using self-efficacy to assess the readiness of nursing educators and students for mobile learning. International Review of Research in Open and Distance Learning, 13(3), 278-297.

Lippincott, J. (2010). A mobile future for academic libraries. Reference Services Review, 38(2), 205-213.

Lombardo, N., \& Honisett, A. (2014). One tool for many tasks: Integrating iPads into the thirdyear learning experience. Medical Reference Services Quarterly, 33(1), 17-28. doi:http://dx.doi.org/10.1080/02763869.2014.866445

Martin, F., \& Ertzberger, J. (2013). Here and now mobile learning: An experimental study on the use of mobile technology. Computers \& Education, 68, 76-85.

Miller, W. (2012). iTeaching and learning. Library Technology Reports, 48(8), 54-59.

Morris, J., \& Maynard, V. (2010). Pilot study to test the use of a mobile device in the clinical setting to access evidence-based practice resources. Worldviews on Evidence-Based Nursing, 7(4), 205-213. doi:http://dx.doi.org/10.1111/j.1741-6787.2009.00171.x

New Media Consortium \& National Learning Infrastructure Initiative. (2005). The 2005 Horizon Report. Austin, TX: New Media Consortium.

New Media Consortium \& EDUCAUSE Learning Initiative. (2006). The 2006 Horizon Report. Austin, TX: New Media Consortium.

New Media Consortium \& EDUCAUSE Learning Initiative. (2007). The 2007 Horizon Report. Austin, TX: New Media Consortium. 
New Media Consortium \& EDUCAUSE Learning Initiative. (2008). The 2009 Horizon Report. Austin, TX: New Media Consortium.

Oliaro, L., \& Trotter, C. (2010). A comparison of on-campus and off-campus (or distance) social work education. Australian Social Work, 63(3), 329-344. doi: http://dx.doi.org /10.1080/0312407X.2010.496866

Ortega, L., Plata, R., Rodriguez, M., Gonzalez, J., Herraiz, J., De Mesa, J., ... Tortosa, S. (2011). Using M-learning on nursing courses to improve learning. Computers Informatics, Nursing: CNI, 29(6 Suppl), TC98-TC104.

Parsons, G. (2010). Information provision for HE distance learners using mobile devices. Electronic Library, 28(2), 231-244.

Shadle, S., Perkins, R., Lincoln, D., Humphrey, M., \& Landrum, E. (2013). Leading a multiple project mobile learning initiative: The approach at Boise State University. EDUCAUSE Research Bulletin, (April 9), 1-12. Available online: http://www.educause.edu/library/resources/leading-multiple-projectmobile-learning-initiative-approach-boise-state-university

Shen, J. (2011). The e-book lifestyle: An academic library perspective. Reference Librarian, 52(1/2), 181-189.

Taylor, J., Dearnley, C., Laxton, J., Coates, C., Treasure-Jones, T., Campbell, R., \& Hall, I. (2010). Developing a mobile learning solution for health and social care practice. Distance Education, 31(2), 175-192.

Tees, T. (2010). Ereaders in academic libraries-A literature review. Australian Library Journal, 59(4), 180-186.

Viberg, O., \& Gronlund, A. (2013). Cross-cultural analysis of users' attitudes toward the use of 
mobile devices in second and foreign language learning in higher education: A case from Sweden and China. Computers \& Education, 69, 169-180.

West, M., Hafner, A., \& Faust, B. (2006). Expanding access to library collections and services using small-screen devices. Information Technology \& Libraries, 25(2), 103-107. 